\title{
Nucleolar Organizer Region
}

National Cancer Institute

\section{Source}

National Cancer Institute. Nucleolar Organizer Region. NCI Thesaurus. Code C13267.

Nucleolar organizer regions (NORs), which are loops of DNA containing ribosomal RNA genes, have been shown to correlate with cell proliferation and malignant transformation. 